\title{
ГЕРОЙ УКРАЇНСЬКОЇ ЧАРІВНОЇ КАЗКИ: ЕТАЛОННІ ЯКОСТІ ТА ПОВЕДІНКОВІ ХАРАКТЕРИСТИКИ
}

\author{
ЛЕСЯ МУШКЕТИК \\ Інститут мистецтвознавства, фольклористики та етнології \\ ім. М. Т. Рильського НАН України, Київ - Україна \\ mushketik@ukr.net \\ BOHATER UKRAIŃSKIEJ CZARODZIEJSKIEJ BAŚNI: \\ CECHY WZORCOWE I MODELE ZACHOWAŃ \\ ŁESIA MUSZKETYK \\ Instytut Sztuki, Folklorystyki i Etnologii imienia M. Rylskiego \\ Narodowej Akademii Nauk Ukrainy, Kijów — Ukraina
}

STRESZCZENIE. W artykule dokonano analizy obrazu bohatera ukraińskiej czarodziejskiej baśni ludowej jako ideału i wzoru do naśladowania. Na materiale motywów baśniowych wyróżniono jego atuty i cechy wzorcowe, będące wyrazem aksjologicznego i dydaktycznego charakteru narratywów baśniowych.

\section{HERO OF THE UKRAINIAN FAIRY-TALE: REFERENCE PROPERTIES AND BEHAVIOR FEATURES}

\author{
LESIA MUSHKETYK \\ Rylsky Institute of Art Studies, Folklore and Ethnology of Ukrainian Academy of Sciences, \\ Kyiv - Ukraine
}

ABSTRACT. In the article there has been considered the hero type of Ukrainian folk fairy tale as a national ideal and role model. In particular on the material of the stories based on the tales it has been highlighted the main advantages and behavioural characteristics, which is the manifestation of the axiological and didactic direction of the fabulous narratives.

\footnotetext{
Д

о скарбниці українських народних казок увійшли імена фольклорних персонажів, які стали називними, промовистими, упізнаваними, надовго закарбувалися в людській пам'яті. Серед них Котигорошко, Іван-царевич, Кирило Кожум'яка, Бух Копитович, Стрілець-молодець та ін. Вони спільно з літературними героями складають когорту так званих вічних образів, які, концентруючи досвід народу, репрезентують нескінченну для людства боротьбу між добром та злом. Водночас образи-персонажі народної чарівної казки суттєво різняться від літературних. Через характеристику персонажів, їхні художні портрети автор прагне висловити головну ідею. Це вираження відбувається по-різному в літературному та фольклорному творах, де образ підлягає замислу. Оповідач повинен донести до слухачів / читачів вироблені віками правила виживання в суспільстві, моральні норми, яким треба слідувати, адже казка своєрідний світоглядно-естетичний і етичний кодекс народу. Для цього він нехтує правдоподібністю, змушує дійових осіб чинити так, як йому потрібно, ставить їх у нереальні ситуації, актуалізуючи дидактичну, спрямовальну, регулювальну та ін. функції в казці: це так звана автор-функція.
} 
Персоналістське спрямування казки виявляється через властиву їй героєцентричність. Саме тому герой стає втіленням кращих людських якостей, $€$ прекрасним як зовнішньо, так і внутрішньо, тобто досконалим у всьому: його вчинки й дії - показові, еталонні, адже уявлення про кращі людські риси формувалися віками із чітким поділом на негативне й позитивне в довкіллі, що й визначає специфіку формування образів. О. Потебня писав: „Байка $є$ один із способів пізнання житейських стосунків, характеру людини, одним словом, усього, що стосується морального боку життя людей”'1.

Казкова персонологія здавна цікавила як дослідників фольклору, так і багатьох митців, які вводили їх до своїх творів. Українським казкам присвячено грунтовні монографії М. Гиряка, Л. Дунаєвської, Л. Мушкетик². Про чарівну казку та їі дійових осіб писали знані українські фольклористи М. Грушевський, Г. Сухобрус, В. Юзвенко, О. Дей, В. Шабліовський, М. Демедюк та ін. Окремим аспектам розгляду казкових персонажів присвячено праці російських та ін. зарубіжних фольклористів - В. Проппа, М. Новикова, С. Мелетинського, О. Новик, Б. Кербеліте і т. д. Внутрішній світ героїв народних казок аналізували Л. Савицька, І. Рагозіна М. Кравцов, П. Богатирьов, В. Бахтіна та ін.

Мета цієї роботи - репрезентація образу головного героя як народного ідеалу людини, його позитивних рис і поведінкових характеристик, що реалізовуватимемо на матеріалі сюжетів та мотивів української чарівної казки.

Зазвичай у казці протагоніст не має імені, а діє як узагальнений тип, що має певний соціальний, віковий, статевий, етнічний статус. Це може бути хлопець, бідняк, чоловік, сирота, або ж царевич, королевич, солдат, пастух тощо. Герой може мати ім'я чи прізвисько (Іван Сученко, Козак Мамарига, Перчик, Найда, Попелюх та ін.), які служать засобом номінації та індивідуалізації персонажів за подібними особливостями - соціальними, психологічними, віковими, фізичними, функціональними.

Ідеальним персонажам властивий ідеальний набір дій, учинків, окреслених стосунків, емоцій і моральних цінностей. Протагоніст має типову зовнішність і атрибути (часто це загальнооцінні епітети, напр. красний, що охоплює сукупність ознак). Зовнішній вигляд та ім'я героя відповідають його внутрішнім якостям, є лише позитивними й відображають народні уявлення про ідеальні людські риси, що розкриваються в ході сюжету казки, дій та вчинків головного персонажа, тобто особистість героя виявляється в його діяннях, реакції на довкілля. Фабула, ситуації, у яких опиняється герой, служать розкриттям і доказом позитивних рис людини загалом, правильності ії кроків, що відповідають нормам поведінки в суспільстві. Народ наділяє протагоністів якостями, зміст яких йому близький і зрозумілий, а спрямованість їхньої діяльності відповідає уявленням про правильне / неправильне. Витоки змістових характеристик антагоністів пов'язані з приписуванням антигероєві рис, не симпатичних людям.

Казкових героїв можна умовно поділити на два типи: богатирі і прості люди, тобто реальні, справжні герої, а також, так би мовити, приховані (герої-невдахи,

\footnotetext{
${ }^{1}$ А. А. Потебн я, Теоретическая поэтика, Москва 1990, с. 8.

2 М. Гиряк, Украӥнські народні казки Східної Словаччини, Братислава-Пряшів 1983; Л. Ф. Дунаєвська, Украйнська народна казка, Київ 1987; Л. Г. Мушкетик, Персонажі української чарівної казки, Київ 2014; Н.В.Но в и ко в, Образы восточнославянской народной сказки, Ленинград 1974; Е. С. Но в и к, Система персонажей русской волшебной сказки, [в:] Типологические исследования по фольклору, сборник статей памяти В. Я. Проппа (1895-1970), Москва 1975, с. 214-246; Б. Ке рб ел и т е, Типы народных сказок: структурно-семантическая классификация литовских народных сказок, в 2 кн., Москва 2005.
} 
Герой украӥнської чарівної казки:

еталонні якості та поведінкові характеристики

“іронічні щасливці”), внутрішня сутність яких розкривається впродовж дії казки. Герой-богатир, як утілення добрих начал, стоїть на боці знедолених і слабких, $є$ захисником своєї держави й повинен бути сильним і мужнім. Сила для героя-богатиря означає те саме, що краса для дівчини. У світі, де точиться боротьба за виживання, перемагає найсильніший.

Щодо конкретних чеснот, то хоч і не всі герої наділені богатирською силою, вони всі сміливі й не бояться ні труднощів, ні поєдинків із чудовиськами, прямують до своєї мети, у чому їм допомагають чарівні помічники. Власне, вони зображені в казці як звичайні люди зі своїми переживаннями й недоліками. Часто казковий персонаж боїться чудовиськ, зміїв, із якими він змагається, та почуття обов' язку виявляється сильнішим, він переборює цей страх, не зважає на нього, йде в цей страх і перемагає його. Він не вагається, а діє, i - будь що буде. Отже, у народній казці утверджується думка, що сміливою $є$ не та людина, яка нічого не боїться, а яка заради своєї благородної мети стає сміливою.

Кожна пересічна людина чогось боїться, адже страх — одна з основних людських емоцій, що сприяє виживанню людини. Людина, яку нічого не лякає, викликає подив: така людина втрачає життєву орієнтацію, адже страх - iнстинкт самозбереження. Так, героя казки Про Андрійка, щео не знав страху називали "дурним, бо не знав він, що таке страх". Сюжет цей повторюється в багатьох казках - ATU 326А Про юнака, який хотів знати, щцо таке страх ${ }^{3}$.

Герой чарівної казки завжди цілеспрямований: він іде до мети, не зважаючи ні на що, не знаючи вагань і сумнівів: Баба питає: - A, слихомь слихаты Сухобродзенка богатыра, а у вічи видаты; то було сльшно, теперь и у вічи видно. Чи по воли, чи по неволі? - По волі, - каже той, - бо добрый молодець не ходить по неволі $i^{4}$ У чарівній казці протагоніст завжди реалізує свої прагнення через долання труднощів і перепон. І робить це тому, що має велику силу бажання, віру в його реалізацію i, відповідно, силу волі, яку він загартовує під час виконання важких завдань і поєдинків з ворогами. Адже труднощі, із якими зіштовхується людина на шляху реалізації свого бажання, ще більше посилюють його, мобілізують для досягнення мети. Отже, тут убачаємо оптатив як провідний модус казкової оповіді, вихідною передумовою розгортання якого $€$ сила волі героя, тому одна з основоположних ознак актанта - інтенціональність, художні характеристики якої знаходимо в досліджуваних текстах. Інтенції персонажа виражені в таких висловлюваннях: йдемо світом щастя шукати; куди мені йти, аби щастя-гаразду знайти; йти пробувати / шукати щастя тощо. Це загальне місце часто повторюється в казці. Під пошуком щастя розуміємо пошуки матеріальних статків, кохання, подружньої пари, набуття життєвого досвіду, знань, ремесла, випробовування сил тощо.

Героєм рухають позитивні, благородні цілі, саме за допомогою позитивних якостей героя казка допомагає йому вершити подвиги - винагороджує його, оскільки герой отримує те, до чого прагнув: одружується з коханою, а на додаток - те, що за казковою логікою, потрібно людині для щастя: царство чи півцарства, чарівні предмети і тварини, надзвичайні здібності та ін., тобто він отримує все, чого тільки може побажати людина.

Більшість подій чарівної казки зосереджена навколо дороги, шляху, відносно стабільною є сюжетна схема: дім - дорога — ліс — інше царство. Тут „шлях

${ }^{3}$ ATU - The Types of International Folktales: A Classification and Bibliography. Based on the system of Antti Aarne and Stith Thomps on, By Hans-Jörg Uther, Helsinki 2004, Part. 1- III.

${ }^{4}$ Труды этнографическо-статистической экспедиции въ Западно-Русскій край, Матеріаль и изследованія, собр. д.-чл. П.П. Чуб ин ск и м ь, СПб. 1878, т. 2, с. 311. 
героя ніби уособлює вісь оповідання. Це - найдавніша форма композиції. Оповідання закінчується або поверненням додому, або прибуттям його в інше місто чи в іншу землю"5. I якщо брати героя за найменших труднощів звертають з вибраного шляху, то герой іде до кінця і перемагає. Щоб увиразнити перепони, які стоять на його шляху, у сюжет вводять різноманітні важкі завдання, які він має виконати. Це може бути зведення палацу, моста із золота, срібла чи діамантів, збирання врожаю та ін., і все це за умови виконання упродовж одного дня чи ночі тощо. Герой має пасти кобилиць Баби-яги, які є іiі дочками-чарівницями, пильнувати їх. Такі своєрідні гіперболи неможливого й репрезентують казкову фантастику. Вони збуджують певні емоції - це і переживання за долю героя, жаль до нього, подивування швидкістю виконання завдань і дивовижним зовнішнім виглядом, радість через щасливе завершення епізоду, покарання чи висміювання ворогів тощо. У виконанні завдань і досягненні мети героєві допомагають чарівні помічники, які можуть бути людьми чи тваринами, птахами тощо. Із часом первісно міфологічний мотив допомоги набуває в казці морального спрямування. Тут відображається й притаманний людям альтруїзм, коли потреба допомагати іншому є покликом душі, порухом серця, виявом любові до людей, природи, життя. Це може бути вияв жалісливості й чутливості натури, а іноді й стимул відволіктися від власних проблем. Помічники приходять на допомогу лише позитивним героям, за їхні якості, що виявляються в попередніх учинках і діях: проводиться думка, що, по-перше, щасливу долю треба заслужити, а по-друге, іiї достойна лише людина з позитивними якостями, яка є доброзичливою до всього навколишнього світу, тобто казка демонструє мериторизм - принцип відплати за чесноти, що реалізується на прикладі головного героя.

Саме внутрішню, моральну активність героя чарівної казки виокремлює В. Бахтіна, яка зазначає, що принцип зображення героя має бути пов'язаним 3 моральними ідеалами, оцінною значущістю людини, а не 3 її роллю в певних моментах сюжету: „Не завжди бездіяльність героя можна вважати ознакою його пасивності. Необхідно враховувати і внутрішню готовність до дії, і намір досягти своєї мети, які завжди властиві казковому герою. В. Я. Пропп справедливо підкреслював, що „«його» (героя) наміри утворюють стрижень оповіді” (Морфология сказки, с. 129). Нарешті, для казки як жанру набагато значущішою $€$ моральна активність героя, що виявляється в його взаємодії з довкіллям"б.

Як і в житті, у казках людині властиво помилятися. Так, не послухавшись поради помічника, актант може втратити кохану чи навіть життя. Казка може починатися зав'язкою, коли супротивник за певну послугу тощо просить у чоловіка віддати йому найдорожче, що $є$ в нього дома (СУС $-811^{*}$ Biдdaй те, чого не лишив удома (казка Чорт та запродані діти)). Той, не підозрюючи підступу, обіцяє. Найдорожчою виявляється новонароджена дитина, про яку чоловік не знав.

Інколи герой із цікавості порушує певне табу — входити до забороненої кімнати, озиратися під час утечі, випускати на волю супротивника, спалювати шкуру жінки-жаби та ін. Він таким чином не дотримується правил, пов'язаних 3 найдавнішим періодом існування людства, це, зокрема, заборона оглядатися під час визволення рідних з країни мертвих (мотив Орфея), порушення табу

${ }^{5}$ В. Я. Пропп, Морфология сказки, Москва 1969, с. 309.

${ }^{6}$ В. А. Бах ти на, Об активности героя русской волщебной сказки, [в:] Фольклор народов РСФСР, Уфа 1976, вып. 3, с. 27. 
Герой украӥнської чарівної казки:

еталонні якості та поведінкові характеристики

в стосунках $з$ дружиною-тотемом тощо. Однак із часом цей підтекст забувається і набуває нового смислу — герой постає як звичайна людина, яка може припускати помилки і виправляти їх, напружуючи свої сили. Причиною їх може бути просто незнання героєм ситуації, як у разі із дружиною, чи звичайні людські слабкості - зайва цікавість, поспішливість, навіть зайва довірливість і жалісливість, тобто казка констатує, що людина не є довершеною істотою, таких не буває загалом. Наслідки помилок можуть бути значними й обертатися новими колізіями, а для героя - подоланням значніших труднощів і перепон. Отже, герой вчиться на власних хибах, пропускає все крізь власний досвід, що впливає на його поведінку, закарбовується в пам'яті і уможливлює в майбутньому не повторювати помилок, принаймні до цього спонукає сюжет казки, унаочнюючи покарання, яке несе герой за неправильні вчинки.

За що ж винагороджується герой казки? Які його риси так приваблюють персонажів і тих, хто складав, переповідав і слухав ці казки?

Насамперед це доброта, адже сила без доброти властива й негативним персонажам. Часто в чарівні казки вводиться мотив допомоги чи порятунку людей, тварин, які згодом “стають у пригоді”, віддячують герою за доброту і людяність, співчуття до слабких і беззахисних (ATU 554 Вдячні тварини, СУС -554** Юнак рятує муху). Герой шкодує навіть маленьку мишку; так, в одній із казок сама подія та емоції героя передано внутрішньою мовою, що увиразнює його душевне благородство: ...Раз лиш видить: мишка. „Пропала би, як я напудився!.. Зараз тебе вдарю так, щуо тобі геть очі повискакують!”' А потім сам від себе засоромився. За щзо бити мишку? Може, голодна й шукає собі їсти? Посягнув у тайстрину, відломив хліба й кинув їй. Тоді мишка проговорила...?.

Зрозуміло, що в давні часи про доброту не йшлося, природа не знає жалості, люди перебували зі звірами-тотемами та духами в особливих договірних стосунках, а трактування дій героя як доброчинності прийшло із часом. У мотиві допомоги повторюються усталені стереотипні формули, що переходять із казки до казки: Як даси, то ми тобі у великій пригоді станемо; а не даси, так не будеш на Русі чи Ну, спасибі тобі, Іване Голику, не дав ти моєму війську проnacmu, не дам я й твоєму. I справді, у тяжку хвилину вдячні тварини, комахи та риби приходять на поміч. Миші допомагають у виконанні марудного завдання - розібрати 300 скирт, щуки знаходять перстень молодшої дочки царя, кинутий змієм до моря, а комар допомагає вгадати, котра 3 дівчат є молодшою дочкою змія.

Аби відтінити якості головного персонажа, казка ставить в аналогічні ситуації його егоїстичних та бездушних братів, які не витримують випробувань. Вони, як і інші антиподи, протистоять героєві, адже його образ розкривається у складній системі сюжетних протиставлень. Антитеза - це, як відомо, художній прийом, за допомогою якого центральний образ набуває поглибленої характеристики. Протиставлення героя його противнику набуває особливої ваги, оскільки стосунки цих персонажів є вираженням різних принципів і так стають засобом ідейного розкриття твору.

Існує чимало казок, що грунтуються на опозиції старший (старші) бра$m u$ - молодший, зокрема в чарівних казках старші брати зраджують молодшого, вони хочуть вбити чи навіть убивають свого брата, забираючи те, що він здобув, й обмовляють його. Молодший брат здогадується про їхні наміри і об-

\footnotetext{
${ }^{7}$ Казки одного села, запис текстів, післям. та прим. П.В.Лінтура, упоряд. Ю. Д. Тур я н и ц я, Ужгород 1979, с. 303.
} 
дурює їх, зокрема в мотиві про витягування його 3 підземного царства, коли останній замість себе прив'язує камінь.

Скривджений у казках завжди молодший брат, однак він $є$ кращим і здібнішим від своїх братів. Симпатії казки завжди на його боці. Можливо, причиною цього $є$ його молодість, різниця у віці, через що молодший брат може бути скривджений старшими - розумнішими, досвідченішими, i тому молодший заслуговує на прихильність слухачів. Дослідники по-різному пояснюють цю обраність - правом давнього майорату (С. Мелетинський), пошуками шлюбної пари (О. Новик), ініціаційними випробуваннями (В. Пропп). Можливо, виявляються релігійні впливи. Молодші діти в сім'ях чи “діти старості”, як правило, вибрані: Свята Діва, Іоанн Предтеча, Ісак, Йосиф. Зрештою, цього може вимагати структура самої казки, характерне для твору потрійне повторення досягає кульмінації саме на третій раз.

Доброта в казках цінується вище, ніж розум: „Народ любить трохи дурненьких, але хороших, і не сприймає розумних, які думають тільки про себе”, писав В. Пропп ${ }^{8}$.

В уста помічників героя, зокрема старих людей, дідів тощо, народ укладає крилаті слова, сентенції, що служать ілюстрацією до ситуації і виражають нагромаджену віками народну мудрість, як це ми бачимо, напр., у казці Торба з иісарем про жовніра Івана: Іде собі й на сопілиі грає. Коло шания побачив діда, що простягав руку й просив: - Дайте, не минайте! Спроможіть, чесні люди, бідного чоловіка. - Одні дають, а інші минають. Хто добре слово скаже, а хто й каменем шпурне. Дід усе приймає. - Іван дістав із кишені крейцара і поклав старому на долоню. Дід на те сказав: - Хто в біді дає, той два рази дає. — Жовнір махнув рукою, приклав до вуст сопілку і пішов собі далі. - Через якийсь час знову здибав діда з простягнутою рукою. Чи ие той самий, чи вже інший - навіть не подумав. Дістав з кишені і другого крейцара й поклав старому на долоню. Дід промовив: - Від доброго чоловіка і крейщар - маєток... Іван пішов далі. - Довго йтов чи мало, я не знаю, але на краю якогось села той самий дід ще раз простягнув до нього руку: - Дайте, не минайте... - Іван дістав останнього крейцара й дав жебракові. Дід йому сказав: - Хто сам нічого не має, а іншому дає, у того добре серие. Я тобі віддячу за доброту та шедрість. Скажи, чого ти хочеш? - Жовнір подумав і відповідає: - Нічого мені не треба, бо якби щось мав, то не було б у чім носити. Хіба щьо дайте якусь торбу, аби-м поклав у дорозі кавалок хліба 9 . Отримавши чарівну торбу — варто лиш сказати “фіть до торби” й “усе летить туди і вже не виходить”- жовнір подорожує з нею, допомагаючи людям - годує голодних, визволяє скривджених, наказує жорстоких та зажерливих.

Душевна доброта, готовність до самопожертви задля допомоги іншому може бути такою сильною, що персонаж казки Брати-сироти $i$ батьківська порада Василь іде на подвиг - спалює свою хату, аби тим попелом посипати страшну рану на грудях старого вісімдесятирічного діда-жебрака. Рана загоюється, а дід-чарівник, який у даному сюжеті покликаний випробувати синів, чи дотримуються вони батьківської поради слухати один одного, жити у порадi $i$ згодi, старшому честі не уривати, бідному допомагати, винагороджує Василя та його сім'ю новою красною світлицею.

\footnotetext{
${ }^{8}$ В. Я. Пропп, Русская народная сказка, Москва 1984, с. 278.

9 Чарівне горнятко: казки, запис текстів С. Далавурака, М. Івасюка, В. Банду рака та С. Пушика, упоряд. С. Далавурак та М. Івасюк, Ужгород 1971, с. 73-74.
} 
Герой украӥнської чарівної казки:

еталонні якості та поведінкові характеристики

У всіх цих ситуаціях важливим $є$ те, що герой діє безкорисливо, виходячи лише 3 добрих почуттів, він щиро жаліє слабшого і не чекає віддачі, яка приходить сама собою як винагорода. У казках відбилися також релігійні уявлення про допомогу іншим. Це, зокрема, заповідь любити ближнього як самого себе, тобто безкорисливо, допомагати слабшому й обездоленому, подавати милостиню, співчувати. Адже основне поняття релігії - Бог як любов. Любов тут постає як глибоке душевне здоров'я. Роблячи добро іншим, людина робить добро i собі. Тому подача милостині жебракам, інші вияви співчуття до людей — це обов'язок кожного.

За більш прагматичного підходу навички допомоги іншим формувалися вже як принцип виживання, адже людина - суспільна істота: вона розуміє, що, допомагаючи іншим, можна розраховувати на них у скрутних обставинах життя. Завжди був дієвим принцип “ти мені - я тобі”. У селянському середовищі це виявлялося у спільних сусідських, громадських роботах, зокрема в період жнив (толока) та ін.

Людські почуття йдуть від серця, тож у зображенні доброти часто згадується серце, а сама людина може бути сердечною, що простежуємо і в описах діянь, і в прямій характеристиці героя. Добрий - це м'який, з відкритим серием, лагідний тощо.

Доброта головного персонажа поєднується зі скромністю та чемністю. Він не вихваляється подвигами, поводиться скромно й виховано, за що його люблять люди і винагороджує казка: Був собі один чоловік, щяо мав трьох синів. Два були пияки і батярчуки, а третій, Степанко, тихий $і$ такий чемний, щяо й куриі "чіт" не скаже ${ }^{10}$. За народною мораллю, велике значення має повага до старших за віком людей: їх повинні слухатися та поважати молодші. Це з дитинства виховують батьки. Та найбільше повага до старших виявляється в розмовах з помічниками героя, старими людьми, які трапляються йому в дорозі. Це, власне, $є$ ще одним випробуванням: герой винагороджується за свою ввічливість i гречність. Це підтверджують казкові діалоги: вони стереотипні і входять до структури казкового етикету, порівн.: Іван поклонився красно. Каже йому баба: - Серенчу маєш, синку, що так красно поклонився, бо якби був не поклонився, то була би іззіла тебе. Та й кажи, щяо шукаєш? ${ }^{1 l}$; — Добрий вечір вам, мамко солоденька! Добрий вечір вам, няньку солоденький! - I тобі, солодкий сину". За отриману допомогу він ніколи не забуває подякувати: - Добрий день, бабко! Та й вертаю перстень. - Так я й думала... Рада, щяо ти позбувся біди. Будь щасливий і на пам'ять прийми від мене отой перстень. - Вівчар красно відклонився - iде далi"'12. Як бачимо, протагоніст уживає ввічливі звороти, зменшувальні слова, звертання позитивно-оцінного характеру тощо: матінко, дідику, пресвітлий ијарю, найясніший царю, пане превелебний тощо, властиві українській поведінковій традиції.

Головні дійові особи казок наділені оптимізмом, упевненістю, веселою натурою, часто це "весела бідність". Своєю поведінкою вони нагадують козаків з їхньою звитягою, жартами. М. Демедюк пише: „Герой-богатир української народної казки різниться $з$ огляду на сам стиль казкової оповіді. На відміну від аналогічних образів білоруської та російської чарівної казки, що тяжіє до

\footnotetext{
${ }^{10}$ Там само, с. 170.

${ }^{11}$ Дерев'яне чудо: народні казки, вст. ст., упоряд., підг. текстів та прим. О. І . Дея, Ужгород 1981, c. 47

12 Зачаровані казкою: українські народні казки в записах П. В. Лінтура, упоряд. I. М. Сенька, В.В.Лінтур, Ужгород 1984, с. 361.
} 
стилістики героїчного епосу, невід'ємною рисою українського богатиря стає поєднання епічних та гумористичних характеристик при описі персонажа. У характері, учинках та навіть зовнішності казкового героя простежуються риси українського козака - оборонця слабких та скривджених. На приналежність героя до козацького стану вказує і звертання до нього інших персонажів: «Здоров, козаче»"13.

Так, Іван Богодавець зі своїми побратимами сидить у розпеченій лазні й виспівує пісні (казка Богодавець Іван). Іван Голик, перебуваючи в череві кита, який проковтнув вози $з$ волами та кіньми, ходить по ньому і знаходить люльку, тютюн та кресало. Натоптав тютюну, викресав вогню і запалив собі люльку (Іван Голик і його брат).

Питання та відповіді персонажів відображають також правила гостинності, що існували в тогочасному суспільстві. На думку О. Фрейденберг, інститут гостинності сформувався ще в сиву давнину і сягає корінням тотемічних ритуалів жертвопринесення ${ }^{14}$ : гостя мали привітати, нагодувати й напоїти, покласти спати. У казках це роблять і супротивники героя. Цей звичай певною мірою існує й донині.

Деякі назви казок є сентенціями, що виражають колективний досвід. Так, казка Більше розумом, ніж силою наочно демонструє переваги людського розуму: у цьому перед силою звірів - ATU 157 Тварини вчаться у полохливого чоловіка. Розум виявляється "старшим" не лише за силу, а й за гроші: У сильного - кулаки, а в розумного - довбня, у сильного шабля, а в розумного - панцир, у багатого - гроші, а в розумного - хитрість. Тому й кажу: розум - найстариий ${ }^{15}$. Епітет розумний у народній казці - висока оцінка: тут проводиться думка, що розумна людина краще орієнтується у світі й досягає успіху. Будеш розумний - не загинеш, будеш дурний - пропадеш; Будеш розумний - побачиш (свою матір), будеш дурний - пропадеш. Розум тут дається від народження.

У казках про прихованого героя в зачині йдеться про чоловіка, царя тощо, у якого було двоє розумних синів і один дурень. Таке означення закріплене за молодшим сином за нестандартність його поведінки, висловлювань, дій, які не $\epsilon$ "розумними" і нормативними. Однак у ході сюжету казки, коли для братів настають справжні випробування, найрозумнішим і найкмітливішим виявляється молодший, який допомагає і своїм братам. Така метаморфоза викликає ще більші симпатії до героя, котрий зміг розкрити своє справжнє єство. На початку оповіді він часто зображується комічно, гумористично, що служить приводом для численних глузувань. Комічне в зображенні героя досягається шляхом гіперболізації його ліні, а також підкресленим контрастом його незвичного вигляду, способу дій та вчинків. За цими характеристиками й судять про розумові здібності героя, на нього перестають звертати увагу, уважаючи не здатним ні до чого серйозного, ставляться зверхньо і $з$ насмішкою. Однак диваком і дурником герой $\epsilon$ лише для дійових осіб казки. Читачі, знаючи логіку розвитку подій, відчуваючи ставлення оповідача до героя, віддають свої симпатії скривдженому молодшому брату і сміються над старшими братами, які через обмеженість не

${ }^{13}$ М. В. Демедюк, Національна специфіка украӥнської народної казки, автореф. дис... канд. філол. наук, Львів 2010, с. 15.

${ }_{14}^{14}$ О. О.Фрейде нберг, Миф и литература древности, Москва 1978, с. 139-140.

15 Чарівна торба: українські народні казки, притчі, легенди, перекази, пісні та прислів'я, записані від М.Шопля ка-Козака, упоряд., передм., прим. та словн. I. М.Сенька, запис текстів I. М.Сенька, В. М.Сенька, Ужгород 1988, с. 88. 
Герой украӥнської чарівної казки:

еталонні якості та поведінкові характеристики

розгледіли справжньої суті молодшого, наперед смакуючи чудесні перевтілення героя й покарання братів.

Інколи синонімом до слова розумний служить мудрий. Мудрість може поєднуватися 3 правдивістю: Іван завжди казав правду $i$ був наймудрішим, найсправедливішим суддею, завдяки чому здобув царство (казка Про розумного хлопия Івана).

Філософські питання постають у циклі казок про "роджений і вчений розум", тобто про вроджений розум, життєву мудрість людини, а також набуті нею знання. Так, придуркуватий Іван 3 казки Пройдисвіт отримує в нагороду чарівну паличку і просить зробити його мудрим і вченим. Паличка відповідає: Від сьогодні ти станеш мудрим, а щоб стати вченим, треба йти у світ. I в ию ж мить він зрозумів, що брати годували його лише через те, що боялися йти на ивинтар ${ }^{16}$.

За народними поглядами людина буває мудрою від народження, тобто це їй дається Богом, цьому не навчишся, це залежить від внутрішніх якостей людини, іiї природних даних, розвинутої інтуїції та чуття. Від природи мудра людина на власних прикладах набуває того життєвого досвіду, який називають життєвою мудрістю. За вченим розумом ідуть до школи, а потім і далі - вчаться, здобувають знання. Народ розуміє, що знання потрібні в освоєнні професії, формуванні певних навичок. До того ж “учена" людина має більше шансів на успіх у житті, може зробити кар'єру, обійняти гарну посаду тощо. Тому “вчений” викликає повагу й шанобливе ставлення.

Людина може стати дуже освіченою, використовувати знання у професії, однак ці знання є привнесеними ззовні, вони не здобуті життєвим досвідом, це просто інформація, яка навряд чи знадобиться у складних життєвих ситуаціях. Так казав келечинський казкар Михайло Шопляк-Козак: Мудрість я збирав від молодості, як пчола збирає на квітах мед. Зазвідала мене вчителька, чи я читаю книжки з бібліотеки. „Ні!” - кажу їи. — „А чому?” — „Готовий мед солодкий, айбо той мед, щяо сам найдеш у дуплі, - солодший. Таким медом лікують хвороби" 17.

Та й чи зробить ученість людину кращою, щасливішою, чеснішою. Навряд чи. Навпаки, деякі, вивчившись, забувають про своє походження і стають пихатими та зарозумілими, як це, до прикладу, описано в закарпатській казці Про мудрого діда - ATU 921 В* Злодій, жебрак, убивия. Один заможний селянин “вивчив свойх синів на панів: старшого на попа, середущого на адвоката, молодшого на дохтора". Сини доки вчилися і отримували від батька гроші, любили його і “честували", а як школу закінчили і влаштувалися на службу, забули за того, “хто їх родив і людьми зробив". Минув час, дід посивів, та однаково мав самотужки газдувати, пасти волів. Тим часом дорогою проїжджав цар, який здивувався, що дід сам оре поле. Той повідомив, мовляв, його сини сидять на стільцях - великими панами поставали. Цар здивувався: - Якими панами? Якщо пани, то могли би тебе спромогти. - Ей, панами, та ще якими!.. Один - розбійник, другий - обманщик, а третій - жебрак. - Цар зачудувався: - Діду, щсо ото за пани? - Коби я знав, з ким говорю, я би пояснив. Ну, відпровадьте слугу та вповім вам тайну... - Розбійник - дохтор, бо він ріже людей не шкодуючи і не має серия. Обманщик - адвокат, бо він прийме кожне

\footnotetext{
16 Чарівне горнятко ..., с. 248-249.

17 Як то давно було: Легенди, перекази, бувальщини, билиці та притчі Закарпаття у запиcax I. С енька, Ужгород 2003, с. 279.
} 
діло, хоч добре знає, що з того нічого не вийде, що на суді те діло буде програне... Значить, він обманює людей, лиш аби тисячі загарбати... Жебрак - nin, бо все жебра, все дранчить, все реве, щзо бідно живе... ${ }^{18}$. Чи не звучить це досить сучасно?

Поширеним, як в українських, так і в європейських казках, є відомий міжнародний сюжет про чоловіка, який своєю мудрістю дивує навіть царя і виявляється розумнішим від царських міністрів ATU 922 В (Зображення короля на грошах). Дід, який ставить мудрі питання цареві, отримує від нього сто срібних з умовою нікому не розповідати своєї таємниці, поки не побачить голову царя сто разів. Потому цар скликав своїх міністрів й загадав їм дідові загадки, а хто відгадає - стане старшим міністром. Та один з міністрів виявився хитрим і уклав 3 дідом контракт - за видану таємницю міністр будує тому красну хижу. Міністр розказав відгадку цареві, той дуже здивувався, а потім зрозумів, що дід не дотримав слова. Він почав дорікати дідові, та той нагадав про угоду й сказав, що справді бачив голову царя - сто разів на ста срібних монетах, отриманих від царя. Цар засміявся і повіз діда до палацу. Там посадив усіх міністрів навколо стола, по лівій стороні - міністр, по правій — дідо... Цар ударив міністра в плече і говорить: - Давай далі - вдар свого сусіда і так далі. Дідові приходилося вдарити иаря, але дідо встав і заявив: - Гоп! Далі не б'ємо, бо тут голова нашій державі. - Міністри лише пооглядалися: - Видите, се - розум! Невчений, а закон знає... Дідо має розум природжений.

Часто поради дає синові батько, зокрема виряджаючи в дорогу: Як ти не підеш в дорогу та не проздриш світа, поки я живу, то не будеш відтак знати світові ладу ${ }^{19}$. Батько на наочних прикладах повчає дітей жити дружно - сини легко ламають вийняті по одному з віника прутики, тоді як сам віник ніхто з них зламати не може - ATU 910 F Сварка синів і в'язанка прутиків. Мудрі поради часто дає батько своєму синові чи синам перед смертю - ATU 911*, ATU 915 Все залежить від того, як ти ие зробиш.

Розум може підмінятися хитрістю: зазначені поняття можуть змішуватися. Ю. Лотман писав про це так: „Розумний — це той, хто здійснює неочікувані, непередбачувані для його ворогів дії. Розум реалізується як хитрість... Непередбачуваність дій $є$ ефективною тому, що вибиває противника із звичної йому ситуації..."20 .

Народна симпатія завжди на боці слабшого і скривдженого: „Проблема хитрості - одна з найскладніших проблем казкової поетики. Хитрість $€$ знаряддям слабкого проти сильного. Тому хитрість у казці не лише не засуджується, а героїзується. Сюди відноситься, наприклад, мотив сперечальників...”- писав В. Пропп ${ }^{21}$. Недарма в одній із казок говориться: Треба знати свойх ворогів штукою побороти, як нема такої сили, як вони мають! ${ }^{22}$. Так, у казці Іван Побиван та інших - ATU 1060 Хто роздавить камінь, ATU 1072 Змагання з бігу однойменний герой, бідний парубок, який хоче знищити змія-людожера, змагається 3 ним, та будучи слабшим, використовує хитрощі. Так, він чавить сир, 3 якого тече вода, й каже змієві, що це камінь, чи в змаганні, хто дужче свисне, б'є залізякою змія, і в того вилазять очі, нібито він свисту тощо.

\footnotetext{
18 Зачаровані казкою..., с. 223-224.

${ }^{19}$ Казки Покуття, зібрав О. Кольберг, упоряд., підг. текстів, вст. ст., прим. та словн. I. В. Хланти, Ужгород 2001, с. 147.

${ }^{20}$ Ю. М. Лотман, Внутри мыслящцих миров: Человек, текст - семиосфера - история, Москва 1996, с. 267.

${ }^{21}$ В. Я. Пропп, Русская народная сказка, Москва 1984, с. 188.

${ }^{22}$ В. Гнатюк, Українські народні казки, Львів 1913, с. 128.
} 
Герой украӥнської чарівної казки:

еталонні якості та поведінкові характеристики

У чарівних казках за допомогою розуму та хитрощів герой перемагає набагато сильніших від себе супротивників, як силою, так і здібностями зокрема чарівників. Це говорить про те, що в системі людських цінностей розум переважає над силою, тобто цінується значно більше й має велике значення у пристосуванні людини до навколишніх умов і життя в колективі.

У казках високо цінується правдивість, справедливість, чесність. Народ не любить брехню та обман. Роздуми героя, який потрапив у скрутні обставини і вагається, чи казати правду, психологічно передаються в казці (СУС 889 Вірний пастух) за допомогою цікавого прийому - хлопець провадить уявні розмови $з$ паном.

Відомим міжнародним сюжетом є Правда і кривда - СУС 613 Правда i Кривда. В однойменній казці їх символізують двоє братів: Якось жила собi бідна вдовиия. Мала двох синів. Один хлопець був дуже справедливий, другий несправедливий, бо де тільки міг, всюди чинив кривду. Так мати синів і назвала: молодмого - Правдою, а старшого - Кривдою. Скільки не просила, не умовляла стариого „Не чини людям зла, будь справедливий” - нічого не допомагало, а молодшому говорила — „Синку, стій за себе, не будь такий м'який та дурний”, - та молодиий син іншим і не міг бути. Так брати й повиростали: кожен зі своєю натурою - старший з кривдою, молодший - з правдою 23.

Ці тези ілюструють подальші події казки. Старший брат виявляється жорстоким і за харчі вириває в брата око, відрубує руки й кидає його під шибеницею помирати, натомість менший згоджується на все й не тримає зла, а отримавши назад руки чарівним способом, не мстить братові, а дає пораду, як роздобути багатство. Старший брат і так багатий, “хіба пташиного молока не має”, та й того йому мало, він навіть дозволяє вийняти собі очі й обрубати руки, або робить це власноруч, аби отримати ще більше. Та це йому не вдається. Жорстокого брата за казковими законами покарано, розлючені ворони підвішують його вгору з табличкою на шиї, де написано: Хто лихою дорогою ходить, на такій i пропадає.

Слово правдивість у казках згадується не лише в прямому значенні - казати правду, не брехати, а часто у значенні справедливості в стосунках поміж людьми, чесності, порядності тощо: Та не було в нього нічого, лище дві робочі руки. Та найціннішим його скарбом була чиста совість, бо ией чоловік був такий правдивий, щзо за правду пішов в огонь! ${ }^{24} \mathrm{У}$ чарівних казках герой $є$ справедливим - він завжди бореться за правду і справедливість, карає ворогів і рятує скривджених, виступає на боці слабого тощо: як скінчилася війна, Мирко так поділив землі: старшому братові лишив вітиівщину, середущому — рай, завойований від песиголовиів, а собі-жінчину державу ${ }^{25}$.

Захищати слабкого, нічого натомість не отримуючи, просто задля справедливості, завжди вважалося шляхетною рисою людського характеру. Часто ці поняття змішуються: А хлопець був чесний - решту грушок висипав y такому місиі, щзоб їх ніхто не знайшов 26 . Ідеться про хлопця, який набрав чарівних грушок, від яких виростають роги, ними він “лікував” підступного короля, а потім заховав їх: тут більше пасує слово “порядний”.

${ }^{23}$ Правда і кривда: казки, передм., упоряд. і прим. І. В. Хлант и, Ужгород 1982, с. 172.

${ }^{24}$ Три золоті слова: Закарпатські казки Василя Короловича, запис текстів та впоряд.

П. В. Лінтура, Ужгород 1968, с. 210.

25 Зачаровані казкою..., с. 345.

${ }^{26}$ Казки одного села..., с. 69. 
Чесна людина в казці ніколи не візьме чужого, не зазіхатиме на велике багатство. Так, у Казці про щирого вояка Микола служить у війську, а потому роздає зароблені гроші. Далі працює в дідуся, перебирає золото. За те, що за довгі роки він нічого не взяв, дідусь допомагає йому влаштувати свою долю.

У багатьох казках поняття правдивості набуває соціального звучання, що, безперечно, з'явилося десь із XVI ст. у зв'язку з формуванням нового уявлення про особистість в українській народній свідомості, що зазначає I. Юдкін. У фольклорі з'являється особа, готова брати на себе відповідальність за вчинки і діяти рішуче: „У ліриці та епіці виховується людська гідність, почуття самоповаги, які стали прикметною ознакою українського фольклору. Барокові фольклорні новотвори унаочнюють те, що «низи» суспільства не усвідомлюють себе «низами» і ніколи не змиряться з приниженням"27.

Саме відчуття соціальної несправедливості змушує людей іти в опришки та розбійники, аби боронити людей. Так, у казці Сірак до сірака через царяздирника потерпав увесь народ. Його ненавиділи, але мусили терпіти, бо не було такої людини, яка могла б повести людей за собою. Таким вождем виявився хлопчик-сирота, якого знайшли в житі, звідси й ім'я його - Найденик. Люди називали тих опришків “найдениками”, а також “сірак до сірака" (сіракверхній селянський одяг). У казці є багато влучних спостережень і життєвої правди. Наголошується на важливості очільника, ватажка народних повстань, який має підняти народ і вести його на боротьбу. Така людина народжується нечасто, вона є особливою, оскільки гостро відчуває біль інших, несправедливість і кривду. Помисли такого чоловіка спрямовані на турботу про інших. Він має бути сміливим, безстрашним і досить жорстким, іноді навіть жорстоким. У казках трапляються й інші імена "благородних розбійників", які діяли свого часу в Україні.

Та в народних оповідях звучать і мотиви зневіри у справедливість на цій землі. Адже рівними людей робить лише смерть. В одній із казок розповідається, як господар влаштовує обід і каже, що за стіл посадить лише правду. Йому довелося відмовити усім гостям: їхні вчинки виявилися несумісними з ідеями правди. Навіть Богові відмовив господар, оскільки той дає всі блага одним, а іншим залишає лише турботи. Тоді прийшла Смерть і господар посадив іiї за стіл, бо вона до всіх ставиться однаково.

Ставленнядо праці - джерелажиття наземліє для казкиважливим критерієм оцінки діяльності героя, його поведінки, адже в селянському (хліборобському) суспільстві підносилися працецентричні цінності, сакральність землі і хліба. В образній формі казка розкриває облагороджувальну роль праці. Позитивні герої змалку працюють, допомагають батькам. Такі люди можуть характеризуватися як гарні, вмілі господарі, які вміють газдувати, порівн.: Сирота служив у одного тазди. Той дуже хвалив його: і розумний, гарний, чесний, а такий роботящий, що такого не завжди знайдещ ${ }^{28}$.

У характеристиці дій протагоніста натрапляємо на загально оцінне означення добра, порівн.: А він свою роботу робить. Так тих кобил добре дозирає i ̈̈сти їм добре дає, так їх файно повичищає $і$ повимітає, що ліпше не може бути. Та й слугам добре давав їсти. I вони його добре слухали². Тут для поси-

${ }^{27}$ I. М. Юдкін, Формування визначників украӥнської культури, Київ 2001, с. 69.

${ }^{28}$ Правда і кривда..., с. 252.

${ }^{29}$ Казки Покуття, зібрав О. Кольберг, упоряд., підг. текстів, вст. ст., прим. та словн. I. В. Хланти, Ужгород 2001, c. 98. 
Герой украӥнської чарівної казки:

еталонні якості та поведінкові характеристики

лення враження від працьовитості хлопця вжито ампліфікацію - нагнітання синонімічних тропів чи однорідних конструкцій.

Селянська праця надзвичайно тяжка, чимало зусиль потребує й здобування селянської їжі. У казці Чорт і хліб (ATU 1199А Чорт і хліб) хліб розповідає чортові, як його “мучить” господар - молотить, б'є ціпом, садить і пуч тощо, що служило своєрідним прикладом трудової діяльності.

У казках знаходимо й згадки про майстрів та їхні ремесла, що високо цінуються народом, порівн.: Йду в світ дечого звідати й навчитися. Аби жити, треба якесь ремесло в руках мати. В іншій казці бідний чоловік мав багато дітей, які підросли і кожен 3 них навчився якогось ремесла: Гей, $і$ мав різних ремісників - столяр, коваль, мурник, швець, кравецьь, і ще, іще. Які лише на світі є майстри, всякі були межи синами бідного чоловіка ${ }^{30}$. У казці Про иаревича, султана і виникареву доньку дочка майстра, у яку закохався царевич, каже, що піде за царевича за умови, якщо він навчиться ремесла. Царевич спершу йде до столяра, потім до шевця, кравця й здобуває професію: він навчився гарно шити шапки.

Та найвище цінують працю на загальне благо, що приносить користь людям: Давно-предавно жив у світі чесний чоловік. Із синами - Степан, Петро $i$ Федько - збудував дорогу близьку для людей. Шість місяиів будували. I хто не йде нею, дякує їм, зичить доброго здоров' ${ }^{31}$. У нагороду за це старенький подорожній пропонує їм виконання бажань. Батько хоче бути щасливим, Степан - щоб завжди хліб родив, Федько хоче легко служити у війську, а Петро каже: Хочу бути найліпшим майстром-будівельником, аби мене люди поважали.

Отже, герой української чарівної казки є втіленням кращих людських чеснот, прекрасним як зовнішньо, так і внутрішньо, ідеалом людини, наближеним до ідеалу всього людства згідно із чітким поділом на негативне й позитивне. Ці позитивні якості в казці винагороджуються, ій властивий мериторизм - винагорода за чесноти, що є важливим виховним, дидактичним моментом казки як популярного фольклорного жанру.

\footnotetext{
${ }^{30} \mathrm{Tp}$ золоті слова: закарпатські казки Васил я Короловича, запис текстів та впоряд. П. В. Лінтура, Ужгород 1968, с. 11.

${ }^{31}$ Срібні воли: казки гір і Підгір'я в записах С т еп ан а Пуш и ка, Київ 1995, с. 237.
} 